\title{
The Philosophical Structure of Jonathan Edwards's Religious Affections
}

\author{
No discourses have been more remarkably blessed than those in \\ which the doctrine of God's absolute sovereignty with regard to the \\ salvation of sinners . . has been insisted upon. \\ -Jonathan Edwards, A Faithful Narrative
}

JONATHAN EDWARDS'S CAREER as a pastor, evangelist, and philosopher is unique in American history. His inquiry into Religious Affections demonstrates the range and complexity of thought that enabled him to intertwine these disparate roles in relation to the concept of conversion, a concept equally important to his public career and his private devotion. Edwards describes conversion as a change of the inclinations revealed in the discovery of the "sense of the heart." 1 The subject of conversion is the occasion for Edwards's most profound reflection on the way his biblical tradition coheres with his psychological and philosophical observations. No other subject could be as pivotal for Edwards, and no other book in American religious thought has been equal in effect to the Religious Affections.

The epigraph to this chapter is taken from A Faithful Narrative of the Surprising Work of God, published in 1737, nine years before the Religious Affections. In this first attempt to describe the Great Awakening, Edwards established two fundamental points: first, that genuine conversion always indicates God's sovereign activity, and second, that conversion is a proper subject of discourse. Edwards expanded these two points into a thorough inquiry of conversion, which he understood to be the only sufficient way to assess the Great Awakening critically and defend its good against the critiques of prominent clergy, most notably Charles Chauncy. ${ }^{2}$

Yet Edwards did not respond in kind to his attackers. Rather, he saw the controversy over the Awakening as a chance to address the confusion about the possibility and dimensions of religious conversion. In doing so, Edwards supports the results of the revival as the product of conversion 
that acknowledges God's activity, and he provides a reasoned account of the conditions and consequences of this fundamental change in a person. The argument of Religious Affections stands on Edwards's conviction that "all spiritual discoveries are transforming ... such power and efficacy have they that they make an alteration in the very nature of the soul" (340). This Augustinian character flows through the Religious Affections as Edwards examines the transforming effect of grace and reflective discovery. Edwards finds conversion within his tradition, and his conclusions support the role of the Puritan pastors in this process, addressing one of the primary concerns of his critics. But he also expands the meaning of the discovery of divine reality with his understanding of the soul's faculties and what would constitute a "spiritual" effect on those faculties.

Oddly, conversion is not a prominent theme in studies of Edwards's philosophical theology. Indeed, most commentators focus their attention on the novelty of his theological position or its consonance with other traditions. ${ }^{3}$ By contrast, I argue here that understanding and describing conversion is Edwards's highest reflective goal, and that in the text of Religious Affections he presents a philosophically structured account of religious conversion. Further, I will argue that understanding conversion is essential to taking full account of Edwards's constructive theology and philosophy. I also suggest that the nature of conversion described in the Religious Affections gives us a clear way to relate Edwards's later writings, such as Freedom of the Will and Original Sin, to mention but two, to his earlier career as pastor at Northampton and his involvement with the Great Awakening.

Claiming that conversion is a central philosophical theme opposes some prominent interpretations of Edwards's philosophical theology. Perry Miller, for instance, argues that Edwards discovered the absence of real divinity and turned instead to a naturalism couched in pious language. ${ }^{4}$ Sang Lee brilliantly describes Edwards's novel presentation of relational ontology that yields an aesthetic harmonization of the soul and the universe. ${ }^{5}$ And John E. Smith explores Edwards's critique of Locke, modernism, and traditional theology, which funds later American developments of a philosophy built on "thick" experience. ${ }^{6}$ But what separated Edwards from his contemporaries during the controversy over the Great Awakening is still present in these recent commentators, who are clearly not Edwards's opponents but yet fail to understand Edwards's 
focus on conversion. There is a reluctance to embrace the divine transformation of human souls as the culmination of reflective discovery. The difficulty appears to be centered on accepting the reality of the divine, articulating the need or desire for a radical transformation of the soul, and establishing the cognitive or experiential access that enables a reorientation of an individual's actions toward a moral or supernatural good. For Edwards, however, these difficulties emphasize the importance of conversion and mark it as the beginning of an inquiry into the kind of knowing that is necessary to render all knowing as trustworthy.

Edwards's main rhetorical task in Religious Affections is preventing the adulteration of conversion by enthusiasm, the uncontrolled emotional responses and special "convictions" that attended the Great Awakening. By describing the limits of conversion, Edwards generates a systematic account of the convergence of emotive responses and intellectual content in a new "sense" that issues in an effective change of the soul. Running throughout this description is the theme of discovery: our discovery of God, and God's discovering his reality to us. Edwards uses "discover" in the middle-passive way, the mood of being subject to an influence where the external or internal origin of the content that results from this influence is left vague. Edwards extends the traditional Puritan meaning of conversion to include knowledge, both intellectual and personal, and faithful living as the signs or aspects of a peculiar continuing discovery, not a single, metaphysically occult event. This discovery is the spirit Edwards finds in experimental religion that opens the soul to "a new world of knowledge."

\section{Architectonic in Religious AfFections}

John Smith points out that Edwards is one of America's most systematic and careful thinkers, comparing him to the logician and scientist C. S. Peirce. As a systematic thinker, Edwards works out or works toward a structure of thought. I argue here that the Religious Affections is an example of a thoroughly architectonic reflection. The architectonic evident in the Affections is the structure of spiritual and intellectual discovery that functions as a platform for conversion. This structure forms the outline of a movement from intellectual discovery beginning within the natural faculties that yields (with God's grace) a complete reorientation of those faculties and a conviction of God's active work on the soul, a "salvation 
ready to be revealed."7 Edwards's tone here is one of universal access to the need for and the possibility of experiencing conversion-God's arbitrary choice of applying grace to only a few elect persons does not appear as a limit to conversion in the Religious Affections. Rather, Edwards makes the case that in conversion the soul finds a divine object that is "worthy of full acceptation," to borrow missionary Andrew Fuller's term. To say it plainly, highlighting the structure of conversion will conflict with the tendency to categorize Edwards as a typical predestinarian Calvinist. Edwards insists on both the sovereignty of God and the reality of an active human conversion in the Affections.

Given the extraordinary dimensions of this topic, there is little wonder that the Religious Affections is a puzzling text. Edwards wrote it in three parts, roughly following the pattern of a Puritan sermon of scripture, doctrine, and improvement. The improvement in a Puritan sermon incorporates the scripture and doctrine in a creative expansion of key ideas and makes a practical application of the message for daily living. The scriptural foundation of the Religious Affections in Part I is based on I Peter 1:8, "Whom having not seen, ye love: in whom, though now ye see him not, yet believing, ye rejoice with joy unspeakable, and full of glory" (93). Edwards examines the benefits and the necessity of trials in bringing a person's "state of grace" — as convertedto plain view. Opposition clarifies conversion, and genuine spiritual character is revealed only by the deepest kind of spiritual and reflective conflict. This agonistic frame shapes Edwards's reflection throughout the Religious Affections.

Part II of the Affections is a doctrinal clarification that clears the field of common misconceptions of the process and results of conversion by examining "what are no signs of gracious affections" (127). Edwards presents twelve of these "no certain signs," attacking current formulations of how one might know or be justified in their belief that they enjoy God's grace or have experienced a special revelation. His point in this via negativa is to articulate the limits of conversion by describing possible errors of judgment about one's state. Neither "special revelations" nor enthusiastic responses suffice for good evidence of the influence of God's grace.

Part III is Edwards's "improvement" on the subject of knowing one's state, "Shewing what are Distinguishing signs of truly gracious and holy Affections" (191). The last part of the Religious Affections has drawn the 
lion's share of scholarly attention. Edwards presents twelve "marks" of a soul that has come under God's saving influence, a reflective account of a soul persevering and being proven by the "trial" of the affections.

Edwards gives no outline or explanation for the order of presentation of the twelve signs. This leads many readers to suppose that the signs are a list of topics most important to least, or vice versa, or topics that simply came to mind as Edwards thought through the issues. ${ }^{8}$ On the contrary, I believe that the signs reflect a discrete arrangement and constitute Edwards's architectonic structure of conversion.

Making the case for Edwards's structure of conversion within the twelve signs of affection depends on establishing three main points. First is that a change in a person's faculties is the proper ground for describing conversion, including its divine origin. I treat this subject in the first section of this chapter. The second point is that Edwards's philosophical and theological description of conversion depends on the arrangement of the twelve signs as an argument that has descriptive and performative dimensions. This point turns on the holistic character of the twelve signs as a single unit of thought. This claim of unity requires an explanation of the internal development of the signs that results in a persuasive argument for conversion, as well as the continuity this argument for conversion has with Edwards's larger ministerial purpose. I present this discussion in the second section.

The third point is that the structure of conversion is central to Edwards's experimental religion. Conversion must not only consist in an ordered process itself, but it must also bring order to our religious experience and practice. This dimension of conversion is discussed later in this chapter.

Amid this positive statement of the effective power of conversion, however, we must not overlook the fact that conversion remained a divisive and problematic feature of Edwards's theology. What remains unresolved about conversion may hopefully come clearer in the process of this examination. It is safe to say, though, that every advance in understanding the complexity of conversion can be properly evaluated only by its potential to provide a continuing ground for reconciliation between the realization of God's demand on humanity and the human efforts to respond sufficiently to that demand, and this clearly cannot be matched by any one thinker. This is the task that Edwards, through the Affections, invites us to engage with him. 


\section{The Realm of Faculties as the Ground of Conversion}

Edwards begins the discussion of twelve signs of gracious affection with a simple statement of faith, that "it be plain that Christ has given rules to all Christians, to enable 'em to judge of professors of religion," although it is not God's intention to "give us any rules, by which we may certainly know, who of our fellow professors are his, and to make a clear separation between sheep and goats" (193). This is similar to C. S. Peirce's claim that if the creator of the universe "really Be and be benign," then we would be able to reach a settled opinion about this reality within the limits of fallible reason. ${ }^{9}$ Peirce suggests that this discovery is possible through the communal practice of scientific inquiry, but Edwards develops his inquiry by delving into religious tradition and scripture. Despite these different approaches, both of these thinkers agree that the ultimate character ingredient in the universe, what they call God, is reflected in a genuine change of human character. ${ }^{10}$ Finding the order or principle of human change, therefore, constitutes the ultimate destination of human reflection, and human change in its ultimate form represents the final meaning of the material universe. ${ }^{11}$

\section{Two Kinds of Knowledge}

Unlike Peirce, though, Edwards is committed to the pastoral task of describing the signs of such a conversion to enable individuals to know their own state and to enable a right discrimination of true religion from false. Edwards's use of signs, like Peirce's later semiotic theory, argues against an essentialist model of the soul. Gracious affections are the character of the soul changed in virtue of its relation to God, a change that is evident in the alteration of a person's faculties of willing, understanding, and desiring, not just particular conclusions drawn from these faculties. ${ }^{12}$ In his 1734 pre-Awakening sermon "A Divine and Supernatural Light," Edwards says "There is a twofold understanding or knowledge of good, that God has made the mind of man capable of." He continues,

The first, that which is merely speculative or notional: as when a person only speculatively judges that anything is, which by the agreement of mankind is called good or excellent. ... And the other is that which consists in the sense of the heart: . . In the former is exercised merely a speculative faculty, or the understanding strictly so called, or as spoken of in distinction from the will or disposition of the soul. In the latter the will, or inclination, or heart, are mainly concerned. ${ }^{13}$ 
Both speculative knowledge and heart knowledge depend on faculties, but only a change of inclination and will makes "heart" knowledge possible. The discovery of this heart knowledge is the subject of this sermon. Edwards argues that the nature of divine light and its sensible effects are one and the same thing, that the illumination of divine light affects the desires and evokes the "heart," revealing the holistic nature of the person's willing and inclining toward God. Divine light shows what is "excellent," Edwards's term for transcendent reality met within experience. The "heart" appears as the character of the faculties, a soul brought to substantiality by its being made newly "sensible of pleasure and delight in the presence of [divine excellence]."14

The emerging awareness of God's excellence reveals the reality the faculties now perceive differently than in their natural state. This perception of excellence shows that the natural faculties have been transcended, and this perceived excellence includes both the objective reality of God and the discovery of a new character, the "heart," within the faculties. Edwards is careful to say that this light does not produce a new faculty in a person, but that the natural faculties are enabled to perceive this excellence in its own functioning, a sign that they have been "awakened" or made newly sensible by the influence of divine light.

Signs of Affection and Four Considerations from "A Divine and Supernatural Light"

"A Divine and Supernatural Light" is especially significant for understanding the twelve signs of the Religious Affections, which also treat the possible reorientation of the faculties. Edwards concludes "A Divine and Supernatural Light" with an improvement that exhorts his auditors to "influence" and "move to" divine light by four considerations.

First. "This is the most excellent and divine wisdom, that any creature is capable of," that exceeds "the greatest speculative understanding in divinity, without grace." This knowledge has the most noble object that is, or can be, which is "the divine glory, and excellency of God, and Christ."

Signs

(I) gracious affections are the result of spiritual operations in the heart,

(II) the objective ground of the affections is the transcendentally excellent nature of divine things, 
(III) the love of divine things for the beauty and sweetness of their moral excellency is the first beginning, and spring of all holy affections.

Second. This knowledge is peculiarly "sweet and joyful. This light gives a view of those things that are immensely the most exquisitely beautiful, and capable of delighting the eye of the understanding."

Signs

(IV) arise from the mind's being enlightened to understand or appreciate divine things, becoming a new "sense of the heart,"

(V) they are attended with the spiritual conviction of the reality of divine things, and

(VI) with evangelical humiliation, which arises from the spiritual knowledge of one's own failure in relation to the "discovery of the beauty of God's holiness and moral perfection."

Third. This light "effectually influences the inclination, and changes the nature of the soul." This change "assimilates the nature to the divine nature," namely the glory that is beheld in Christ. The effect of this assimilation is a "saving close with Christ."

Signs

(VII) gracious affections are attended with a change of nature to Christ,

(VIII) that this change differs from a false change in that gracious affections "tend to" the spirit and temper of Jesus Christ, and

(IX) that they yield a softening of the heart and Christian tenderness of spirit.

Fourth. "This light, and this only, has its fruit in an universal holiness of life." This obedience does not arise from a notional or speculative understanding, but from the influence that "reaches the bottom of the heart."

Signs

(X) saints perceive a beauty of symmetry and proportion inhabiting their affections;

(XI) they experience a deepening appetite for more complete spiritual attainments including practical service; and

(XII) this Godliness has its full exercise and fruit in a moral Christian practice which is "perfect obedience."15

The focus of these considerations is the change in a soul's grasp of a divine object, by knowledge, inclination, and a desire for obedience. The correspondence between the considerations and the twelve signs Edwards 
develops in the Religious Affections is striking. Taking each consideration as a heading or summation, the twelve signs in the Religious Affections fall into four groups of three. This alignment between the considerations and the signs suggests that there is a definite structure to the signs, but it also makes it possible to develop the signs and the considerations together as an argument undergirding Edwards's reflection. Let me expand on this alignment by describing the relation I think holds between the considerations and the signs.

The first consideration from "A Divine and Supernatural Light," that the wisdom of God's glory is beyond educated understanding and only possible by grace is developed in the Religious Affections by signs I, II, and III: (I) gracious affections are the result of spiritual operations on the heart, (II) the objective ground of the affections is the transcendentally excellent nature of divine things, and (III) the love of divine things for the beauty and sweetness of their moral excellency is the first beginning and spring of all holy affections (197, 240, and 253-254, respectively).

The second consideration, the superlative character of this new knowledge, collects signs IV,V, and VI: gracious affections (IV) arise from the mind's being enlightened to understand or apprehend divine things through a "sense of the heart" $(\mathrm{V})$; they are attended with the spiritual conviction of the reality of divine things, and (VI) with evangelical humiliation, which arises from the spiritual knowledge of one's own failure in relation to the "discovery of the beauty of God's holiness and moral perfection” (266, 291, 311).

The third consideration concerning the effectual change of the inclination to the glory of Christ is developed by signs VII, VIII, and IX: showing that (VII) gracious affections are attended with a change of nature, (VIII) that this change differs from a false change in that gracious affections "tend to" the spirit and temper of Jesus Christ, and (IX) that they yield a softening of the heart and Christian tenderness of spirit $(340,344,357)$.

The fourth consideration of "universal" holiness, collects signs X, XI, and XII: (X) saints perceive a beauty of symmetry and proportion inhabiting their affections, (XI) they experience a deepening appetite for more complete spiritual attainments including practical service, and (XII) this Godliness has its full exercise and fruit in a moral Christian practice which is "perfect obedience" $(365,376,384)$. 
Having suggested a connection between these texts, let me quickly say how they are different. In "A Divine and Supernatural Light" Edwards hopes to encourage conversion by highlighting the realization of the "spiritual knowledge that God is the author of." "The four considerations develop the desire or expectation that appeals to the person who does not enjoy this light. Edwards's aim is to promote conversion by speaking about, creating in words, the knowledge that unawakened souls desire but have not yet experienced. His object is different in the Affections. Here he examines the same spiritual knowledge as it appears within the living reality of the saints, as the dynamic principle that holds them to God.

Conversion works both ways for Edwards. First, conversion is what he speaks about to draw souls toward the "good" we anticipate in God, and second, he speaks of conversion as an opening into the continuous discovery of the "good" found in the experience of God. In both cases the divine effect of conversion and our realization of it are the same event, whereby God's influence is present in the human experience of a discovery that incorporates the faculties of understanding, willing, and desiring into a spiritual unity. From these two texts it is clear that Edwards treats the faculties as the ground of conversion, both as a feature of existential experience and as the subject for description. In the next section the internal relations of the signs are considered as both the dimensions of a living encounter with the divine and as a way of articulating that encounter.

\section{Signs of Affection as the Content of Conversion}

We must still ask this question: Why does Edwards present twelve signs in the Religious Affections? As I noted earlier, Edwards says he intends to illuminate "rules" by which "all things whatsoever that the minds of men are the subjects of" come to reflect the order of true religion (89). True religion must be qualified. Religion is true, for Edwards, when it has God for its object and not any self-deceptive replacement. Edwards is not the kind of religious dogmatist Charles Hodge claims he is. ${ }^{17}$ Fidelity to orthodoxy is not Edwards's main measure of truth. For Edwards, true religion obtains when "the immediate object of [the soul] is the supreme beauty and excellency of the nature of divine things as they are in themselves" (271). 
The twelve signs of affection bring to view the pivotal transitions of a soul in the discovery of its effective change of inclination toward God and the divine character of the object it seeks with its heart. This discovery of the nature of the soul and God shows the inferential character of Edwards's signs, making the set of twelve signs an instance of the argument for conversion from experience. In this way the twelve signs extend outward as examples of the practical and intellectual inferences central to all discoveries of God and self.

The four considerations from "A Divine and Supernatural Light" represent critical transitions on the way to the conclusion of God's reality that Edwards says is made "by one step" (299). Edwards does not presume intuitional or other knowledge of God revealed by non-natural means. The development in the twelve signs traces the discovery of an object within the "things in [a person]" which carries an authority that is divine - a discovery of God in us. Divine authority is not the end in view of this discovery, but the nature of the discovery itself argues for its divine authority. A contrary condition is that "natural" souls, those not having this light, will have no such authority attending their self-discovery. Let me now treat the signs as they appear in the text, paying attention to both their relation to the considerations of "A Divine and Supernatural Light" and the inferential character of the discovery of God and the soul.

\section{First Consideration: Signs I, II, III}

Signs I-III reflect the coming to awareness of God's objective character, the "divine glory, and excellency of God, and Christ" of the first consideration from "A Divine and Supernatural Light." Sign I is a spiritual sense that is unique to saints, an awakening awareness that shows that there are operations on the heart that are spiritual, supernatural, and divine (197). In classic Edwardsean style, sign II is what the result of this supernatural operation is not. It is not self-interest. "In the love of the true saint," Edwards says, "God is the lowest foundation; the love of the excellency of his nature is the foundation of all the affections that come afterwards, wherein self-love is concerned as an handmaid" (246). The opposition between self-love and the love of God is the first "objective ground" of gracious affection (240). What is at stake here is best described from the vantage of Edwards's essay on "The Mind."18 In this essay, Edwards describes the love of excellence that permeates all being as 
the tendency toward entity. Entity is the unity of manifold being reflected in harmony of arrangement. This harmony is beautiful, and as it draws more and more being into this relationship, entity expands.

Individuals count as entities, for Edwards, since they are able to order their surroundings by beauty and are able to produce or choose harmony in their being. But all entities are relative and dependent on the principle of entity itself. In a work titled "The Mind," Edwards distinguishes between entities (individuals) that partake of this characteristic of being to construct a private and limited harmony, and those that appropriate it as a means of manifesting the universal principle of entity in their relations. The ultimate principle of entity, God, is perceived in universal harmony, and this perception produces those entities in relationship to entity itself. This distinction also separates love from self-love. "Now how improper is it to say," Edwards remarks in the Affections, "that one loves himself because what is agreeable to him is agreeable to him, and what is disagreeable to him is disagreeable, which mere entity supposes. So that this thing they call self-love is no affection, but only the entity of the thing, or his being what he is." "If If the individual is functioning in terms of the natural tendency to entity Edwards does not call this "affection" or love.

An individual develops "affection" by stretching beyond self-interest-and Edwards sees no way this can occur naturally. The only way this stretching beyond is possible is the translation of the principle by which an entity harmonizes being to reflect the principle by which entity itself (God) harmonizes being. In this new state of entity, which is love, the harmony of the individual is the same harmony, but not the same content, as entity itself. The individual expands the being of the entity of God as a new point of expanding the harmony of God's excellence. Love of divine excellence is the sign of a supernatural operation on the heart, not because the natural tendency to entity is eliminated, but because God's harmony of being is appropriated for its "loveliness." The "spiritual sense" of the first sign is this awareness of supernatural excellence within the aesthetic tendency of being, which is shown in opposition to self-love in sign II.

Sign III is the love of God's moral excellence. ${ }^{20}$ Moral excellence is the harmony of relations reflective of God's entity in his "exercises as a moral agent, or whereby the heart and will of God are good, right, and infinitely becoming" (255). Objective reorientation of the individual to 
the entity of God is accomplished when the harmony within the moral character of God is perceived, and Edwards means the character of God revealed in scripture. The transition to love of God's moral excellence is autobiographical of Edwards's own struggle with the "horrible doctrine" of the condemnation of sinners to hell. In his "Personal Narrative," Edwards describes his coming to see that God's eternal judgment of sinners was not simply compatible with the excellence of God's moral character but constitutive of that harmony, at least in terms of human experience. ${ }^{21}$ This assent to the moral character of God in the Bible is an ultimate challenge to the natural understanding because it provides the most concrete material for evaluation and judgment and also because it undermines all previous claims to rational harmony. The love of the moral character of God thus disestablishes the intellectual order of the natural faculties, eliminating the integrity of the natural soul, and opening up in an existential way the need for a new order of the faculties.

Before I proceed to the next consideration and the next cluster of signs, let me make two points. First, Edwards calls the love of spiritual things of sign I the "fountain" of all gracious affections (240). This love is indubitable and immediate, that is, it is not a product of inferential reasoning. Neither can it be further articulated by inspecting preceding conditions. Taken in its immediacy simply as love it is without denotable content. There is the love of the spiritual character, like the love for a parent, which inclines the child to seek the particular acts and decisions that manifest that lovable character, but the love precedes this particularity. Edwards's description of this love as prior to particular content has encouraged a portrayal of the gracious affections as an essentially aesthetic disposition, but I do not think this is complete. ${ }^{22}$ The immediacy of the saint's love of divine excellence reflects an absence of content that propels the understanding to further discovery. Second, the searching out of this excellence, in response to the immediacy of spiritual love, runs on an abductive hypothesis (to reach ahead to Peirce) of a "new simple idea" (205) that might supply the need for an order to the faculties.

Edwards says that natural understanding excels in following out relations of ideas but not in constructing its own origin or order. So the new simple idea that governs the judgment makes it "entirely of a new sort, and which could be produced by no exalting or varying or compounding of that kind of perceptions or sensations which the mind had before.... If grace be an entirely new kind of principle, then the exercises of it are 
also entirely a new kind of exercise" (205). ${ }^{23}$ The focus here is on the nature of the idea governing the understanding, which is revealed by the object the understanding is able to perceive. The object perceivable by the judgment denotes the character of the understanding and also its ordering idea. Edwards establishes the rudiments of pragmatist logic in this connection between our reasoning and the object we can discover with that reason. Recognizing that we have a new or changed understanding requires that a new object has become apparent to our perception.

\section{Second Consideration: Signs IV,V,VI}

The second consideration of "A Divine and Supernatural Light" reads, "This knowledge is that which is above all others sweet and beautiful ... capable of delighting the eye of the understanding." Edwards begins sign IV with a more general point, "gracious affections do arise from the mind's being enlightened, rightly and spiritually to understand or apprehend divine things" (266). "Knowledge," he says, "is the key that first opens the hard heart and enlarges the affections" (266), and the knowledge that is significant "appertains to the salvation by Christ, whereby he now sees how it is, and understands those divine and spiritual doctrines which once were foolishness to him" (268). Here Edwards introduces the sense of the heart: "I say a sense of the heart; for it is not merely speculation that is concerned in this kind of understanding; nor can there be a clear distinction made between the two faculties of understanding and will as acting separately and distinctly, in this matter" (272). Edwards's claim, contra Locke, is that the understanding operates only in strict relation to the order of the inclination, which incorporates the will. ${ }^{24}$

The sense of the heart is the unity of the faculties, where the ordering principle of the understanding and the will coincide. This coincidence is a "sense" because it is not a property of either the will or the understanding. The result of this new principle is not a change in the way the understanding works, but the substantial character it yields to the faculties that was not present before. Edwards does not ascribe to an intuition of the self, or a moral sense that unifies the inclinations, as in Butler's Analogy of Religion. ${ }^{25}$ The sense of the heart, Edwards says, is "an effect and impression the soul is the subject of, as a substance possessed of taste, inclination, and will" (272, my emphasis). The unity of the will and understanding is an inferential conclusion which is possible only in relation to the same kind of harmony perceived in divine "things." 
This reciprocal discovery of the substantial character of human and divine reality is the key to Edwards's rational faith. The soul achieves a substantial character as a result of its perception, its sense, of the sort of object that can provide a sufficient order to the understanding and the will, namely "the excellency of Christ's person" (273). The soul becomes a substantial entity as an effect of the understanding and will reflecting the same principle of order perceived in the character of God's moral excellence in Christ. Sign V develops the perception of unity in divine things, which is the basis for the conviction of the reality of the truth of the gospel, "that really Jesus is the Christ, the Son of the living God" (292), a judgment that establishes both the objective nature of God's revealed character and the objective nature of the soul that perceives it. The correspondence between the discovery of the reality of God's character and the reality of personal identity is pivotal in the signs of affection.

Personal identity, for Edwards, is the nexus of will and understanding which becomes substantial as a resisting thing by virtue of a single ordering principle. Edwards's notion of the will is not a power of choosing or refraining from choosing, as he makes clear in Freedom of the Will. Rather, the will arises within a person's faculties when the desires are discovered to have a discrete orientation. Likewise, the understanding is a faculty that has an orientation-it has an "object." In a natural condition, a person's will and understanding have different objects and orders. The question is what makes the understanding a proper function of the will, so that the understanding has the same character or focus as the desires. This occurs only if both the will and understanding have the same discrete orientation - toward an object. The "sense of the heart" is the awareness that the understanding is oriented toward an object that requires its full function to engage and that the will is also constrained by the same object as the proper or satisfying object of the soul's desire. The singular focus on this object by both the intellect and the will means that the inclination of the soul has overcome fragmentation. Fragmentation is a feature of our natural condition in which we are unable to perceive what will unify our hearts. In Freedom of the Will Edwards says that the soul is determined by its choice of an ultimate object, but no natural object is sufficient to incorporate both the intellect and the will. What Edwards means by "freedom of the will" is making this ultimate decision a conscious one. Really exercising the freedom of the will means choosing the character it will exemplify, and this can happen only when the 
will is fully engaged in choosing an object that is proper to its power, which is the object discovered in conversion, the excellence of God in Christ. The grace of conversion is the presence of this object in our tradition and revelation. Without this object, the soul is not able to choose the content that unifies the will and intellect, and so its inclinations remain alien to its own cognizance or willful control.This fragmentation is experienced as the being unto death without grace, the universal state of original sin.

The singular focus of the understanding and the will produce the inclinations into a denotable unity, the heart. But unity is not Edwards's privileged category. Instead of the unity of the heart completing his investigation, it becomes the ground for "evangelical humiliation" in sign VI.The character of the soul's inclination is displayed ultimately through resistance and opposition, a recapitulation of the testing Edwards describes at the beginning of the Religious Affections and which he repeats at every chance (311).

Evangelical humiliation is a sign of gracious affection because this exercise of the affection is possible only when the order of the soul, as an objective character, is found to be in disjunction with the divine willnot finally separated from God, but at odds in its root order. Cognitively understanding the bad ends of actions and owning the failure to pursue conventionally defined goods is what Edwards calls "legal humiliation." This is insufficient for evangelical humiliation because following out these errors cannot support a holistic judgment of the heart, and these relative differences do not reveal the holistic nature of the separation of the soul from God. Evangelical humiliation is indicative of divine influence because it is the discovery that the affective order of the will and intellect is hideous as a whole, which enables a person to "as it were, renounce himself, and annihilate himself" (315).

The discovery of this separation from God is a function of the understanding, since it results from a discerning judgment of the ultimate principle of our natural desires. The knowledge of the heart can be judged as incomplete and lacking in excellence only when compared to God's moral excellence. Judgment is necessary to concretize this lack in human consciousness, but this understanding does not produce a solution or give rest. Rather, this understanding shows the limit of the understanding to describe itself reflexively, since its ultimate principle does not exhibit the excellence to which it is drawn. This judgment also 
reveals the limit of a change of will without the discovery of divine excellence. Evangelical humiliation is the sign that the natural faculties fail to be the beauty the soul desires, but the absence of this beauty is a conclusion of the judgment, a fact made sensible by "the heart." The perception of this "other" beauty becomes the new object of the understanding; as Edwards summarizes, "Unless this [beauty] be understood, nothing is understood, that is worthy of the exercise of the noble faculty of understanding. This is the beauty of the Godhead, the divinity of Divinity ... the Fountain of Good" (274), which becomes, "as it were, a new world of knowledge" (275).

\section{Third Consideration: Signs VII, VIII, IX}

The "new world of knowledge" is present but also absent in the experience of evangelical humiliation. ${ }^{26}$ The felt absence of the sense of the heart, a perception of the "wickedness of sin," results from the sense of the heart seen in relation to God's excellence, although normal models of temporality cannot contain this kind of "resulting." The things of God are wonderfully beautiful, including the sense of the heart, but the understanding comprehends them only from afar, as one outside the gate. The third consideration answers this state of humiliation and fulfills the sense of the heart. Signs VII, VIII, and IX present the individual's conversion, "turning him from sin to God" (341), which is the central dialectic in Edwards's thinking. The immediate limits to this conversion are evangelical humiliation and a turning to "redemption by Jesus Christ, that is the grand subject of the Christian revelation" (346).

In the brief but poignant exposition of conversion in sign VII, Edwards expresses the gracious affection of the human spirit changed to reflect the person of Christ. Just as the centrality of Christ arises in the scripture as the fulfillment of revelation, so the same character arises as the fulfillment of the sense of the heart of the sinner. The Holy Spirit is "united to the faculties of the soul, to dwell there after the manner of a principle of nature, . . a an abiding thing" (342). Sign VIII explores the objective content of this change. Reflecting the passage central to Augustine's conversion Edwards says, "True Christians are, as it were, clothed with the meek, quiet, and loving temper of Christ; for as many as are in Christ, have put on Christ. And in this respect the church is clothed with the Sun, not only being clothed with his imputed righteousness, but also by being adorned with his graces (Rom. 13:14)" (347), 
which are "forgiveness, love, and mercy" (357). This focus on the objective content of Christ's character is of a piece with Edwards's earlier devotion to discovering the ways of God's working. He says, "We must learn the way of bringing men to rules, and not rules to men, and so strain and stretch the rules of God's Word, to take in ourselves, and some of our neighbors till we make them wholly of none effect" (357).

This alteration that produces the character of Christ as the principle of the heart is an opening into the new world of knowledge of a person's convictions of conscience, described in sign IX. Edwards: "This [conversion] don't tend to stupefy a man's conscience; but makes it more sensible, more easily and thoroughly discerning the sinfulness of that which is sinful" (364). The continuing conviction of $\sin$ is a sign that the principle of an individual has altered, even for the saint. Edwards makes a similar point in Original Sin when he declares that the Bible is a source of continuing conviction of sin for humanity, and this is a sign that it is a genuine revelation of the character of God-it will not let humanity rest comfortably in separation from its author. ${ }^{27}$ The conviction of conscience presented in sign IX is the same principle for an individual. This private awareness of conviction is also the necessary ground for the fourth aspect of gracious affections, the moral life of the saint.

\section{Fourth Consideration: Signs X, XI, XII}

The fourth consideration concerns the soul's stretching out in public moral living. This part of Edwards's religious sensibility has been pronounced and, I fear, often disconnected from Edwards's integration of the spiritual sense, the understanding that is ordered by the gracious sense of the heart and the change of nature that produces a new spirit in the person. For Edwards, perfect obedience flows out of the transformed soul only as a reflection of its internal order. It cannot be produced by any natural work or desire. The first sign here, $\mathrm{X}$, indicates "a beauty of symmetry and proportion in the affections" (365). This reference to beauty reflects back to sign I, the spiritual sense of divine harmony. The inclination and taste that reflects divine order likewise perceives the same symmetry in the soul. This self-reflexive awareness of divine order in the soul becomes the ground for genuine "affection" for other people. "The natural body which God hath made," Edwards says, "consists of many members; and all are in a beautiful proportion: so it is in the new man, consisting of various graces and affections" (365). Likewise, a saint's concern for other people is not 
narrowly spiritual, "[b]ut a true Christian love extends both to their souls and bodies [of others]. And herein is like the love and compassion of Jesus Christ" (369). Being inclined to this harmony involves spiritual as well as physical concern for others as the material in which the harmony of soul and body can be manifested.

Sign XI, "spiritual longing and appetite of soul," is the principal tension that expands the saint's desire for harmony internally in the affections and externally in the world. False affections rest satisfied in themselves but gracious affections do not. "The more he mourns for sin," Edwards says, "the more he longs to mourn: the more his heart is broke, the more he desires it should be broke: the more he thirsts and longs after God and holiness, the more he longs to long, and breathe out his very soul in longings after God" (377). The drive to extend the sense of the heart in practice for Edwards is not principally a duty but a positive response to the possibility of an expanding discovery of the spiritual harmony in all aspects of life. "Spiritual good is satisfying," Edwards says, "as there is enough in it, to satisfy the soul . . . there is room enough here for the soul to extend itself; here is an infinite ocean of it." The graciously affected soul is thirsting "until [it] comes to perfection" (379).

Gracious affections have their "exercise and fruit" in Christian practice according to sign XII, but this practice is ordered by the soul's desire for "perfection." The pursuit of perfection is the longing of the soul to abide in behavior universally conformed to "Christian rules" (383). For Edwards there is no other way spiritual order of the faculties can be fully manifested except by governing action and bringing all habits under the rule of order, to the end that the Christian community is itself one of the "things that are made," which reflects God's divine nature. This sign is also the ultimate test of the spiritual principle in a person and a community, since the spiritual nature of one's inclination is irresistibly manifest in practice. "This fruit of holy practice," Edwards says, "is what grace, every discovery, and every individual thing, which belongs to Christian experience, has a direct tendency to" (399).

Edwards calls sign XII the "chief" sign, and some commentators have taken this as a ground to claim that public moral action is the key to understanding the affections. But Edwards, in sign II, says that "the love of the excellency of [God's] nature is the foundation of all the affections which come afterward" (246), and that in sign III, the love of divine beauty is "the first beginning and spring of all holy affections" (253). And 
elsewhere Edwards uses the adjective "chief" to mean the temporally present manifestation of a deeper condition, as Saul's sparing of Amalek is the sparing of the "chief" of the Amalekites, a bodily representation of the opposition to God Saul was supposed to wipe out, and this shows Saul's "chief" $\sin (342)$. Sign XII is chief in this way. Only by considering practice universally is the reality of conversion apparent as the "chief" sign of a person. And this universality includes the complete actions of the individual and the complete actions of the community devoted to "holy practice." ${ }^{28}$ The two ways this sign has been developed show the dangers of reading "chief" as equivalent to meaning the ultimate or most determinative sign. One development results in Samuel Hopkins's doctrine of moral perfectionism, the root of the New Divinity movement, and another development is the raising of practice to the ultimate category in personal identity, as in the thought of William James. Both of these approaches deemphasize some aspect of the conversion I have described here. Hopkins rejects the saint's certain knowledge of their condition of grace, which is precisely Edwards's ground for "true virtue," and William James rejects the reality of God's character and the conviction of his "holy" moral beauty as an essential element in discovering the self.

Let me step back a moment to the beginning reflection on the structure of the signs of gracious affection. I remarked that this structure shows up both as a wholeness of content by which Edwards intends to circumscribe religious experience and as a reflective wholeness. I hope the wholeness of the content of the signs is clearer, although I have presented little more than an outline here. The four considerations of "A Divine and Supernatural Light" as they are developed into the signs of gracious affection represent the access to Edwards's continuing reflective discovery of the freedom of the will, the doctrine of original sin, and the nature of true virtue, and its center in conversion. In this way, the signs of gracious affection represent individual self-discovery, but also serve as a platform from which Edwards's thought extends to all aspects of religion.

In this last section I want to offer a brief reflection on Edwards's experimental religion. Taking the Religious Affections apart, as I have done here, may present a disjointed image of Edwards's main point. But the text weaves these strands of discovery together in a seamless fabric of transcendent experience and God's excellence. Edwards accomplishes this integration of the four general heads of conversion as well as the twelve particular signs with his "experiential" or "experimental" religion. 


\section{EXPERIMENTAL RELIGION}

Much of what Edwards found compelling about conversion challenged his religious tradition. His description of conversion directly opposes the Puritan "order of salvation" which is a theological formula adopted as a form for conversion testimonies used for entering church fellowship. Edwards was sensitive to a different structure that is not formulaic. Indeed, Edwards's notion of conversion demands immediate, personal, and "spiritual" experience. This requirement of experience rules out a religion that is merely intellectual, whether witnessed by moral practice or conventional assent. Only an experience that reveals the new supernatural sense of the heart is sufficient, and Edwards is concerned to point to the places in the lives of people where this discovery is evident. In this way Edwards emphasizes the interdependence of experimental religion and conversion. There are three main points to consider here: the form of practice most likely to result in conversion, the reflective opposition that is a necessary counterpart to realizing the spiritual sense, and the nature of discovery that attends experimental religion.

Edwards defines "experimental religion" as the religious practice of worship, prayer, and study of scripture that becomes the most instructive space for discovering the presence or absence of the new spiritual sense. He says,

not only does the most important and distinguishing part of Christian experience lie in spiritual practice; but such is the nature of that sort of exercise of grace, wherein spiritual practice consists, that nothing is so properly called by the name experimental religion. For that experience which is in these exercises of grace, that are found, and prove effectual, at the very point of trial, or our lusts, are as has been shown already, the proper experiment of the truth and power of our godliness; wherein its victorious power and efficacy in producing its proper effects, and reaching its end, is found by experience. This is properly Christian experience, wherein the saints have opportunity to see, by actual experience and trial, whether they have a heart to do the will of God, and to forsake other things for Christ, or no. As that is called experimental philosophy, which brings opinions and notions to the test of fact; so is that called experimental religion, which brings religious affections and intentions to like test. (452)

Establishing the soul as a fact is Edwards's reflective goal, and the most efficient source of the experience necessary to give this stability to the soul is spiritual practice. Wider experience is certainly a source of spiritual 
discovery, but the content of religious practice is most significant because it brings the soul into direct contact with the most determinative object, the fact of Christ. Edwards says, "For 'tis only by the discovery of the beauty of the moral perfection of Christ, that the believer is let into the knowledge of the excellency of his person, so as to know anything more than the devils do: and 'tis only by the knowledge of the excellency of Christ's person, than any know his sufficiency as a mediator; for the latter depends upon and arises from the former" (273). Discovering the excellence of Christ's person is the experience that most clearly signifies the spiritual sense of the heart.

Recall the scriptural basis of the Religious Affections in I Peter 1:8, from which Edwards shows the necessity of trials for proving faith. He says, "True virtue never appears so lovely, as when it is most oppressed: and the divine excellency or real Christianity, is never exhibited with such advantage, as when under the greatest trials. . . They tend to cause the amiableness of true religion to appear to the best advantage, . . but not only so, but they tend to increase its beauty, by establishing and confirming it, and making it more lively and vigorous" (92-93). What kind of a test can bring the excellence of the soul to view? Only the test of conversion arises to this level of facing the objective character of the self and God. For Edwards conversion is the ultimate trial, where the change to the bottom of the heart comes clear and the character of the soul is continually confirmed. Edwards is not alone in searching for the kind of experience and opposition that will identify the character of a person or a community. Dewey locates this kind of identifying opposition in intelligent practice of the community, Royce finds it in loyalty to an ideal religion, James finds it in the will to believe. Edwards contains this opposition that unfolds in conversion within experimental religion.

The twelve signs of conversion in the Religious Affections contain a pattern of objective content and opposition central to religious experience. Indeed, the second of each trio of signs contains this objectivity and opposition most concretely. Sign II is the first objective ground of affections, Edwards says, the love of God which is not self-love; sign V, the conviction and judgment of the reality of divine things and what is not illuminated understanding; sign VIII, the manifest spirit of Christ in a person, which is not dissension; and sign XI, moral complacency which is not a spirit of discovery. The four movements of the structure of conversion each contain an oppositional and objective core, which directs the process of discovery from the first sign to the last. 
Edwards does not attempt to describe this recurring opposition thematically. I think he does not develop this account because bringing order out of various forms of opposition can be accomplished only in experience, not in any discursive description. Only experience can make the real argument here. Edwards knew that his writing and preaching could not be the instrument of salvation. Preaching is only one occasion among many in which reflective opposition may issue in the discovery of the condition of a soul and the reality of God. The lack of an explicit development of this account of reflective opposition may be Edwards's humble recognition of the genuine mystery of conversion which occurs only in this light; the Spirit blows where it wills and we cannot see from whence it comes, but we can see its effects, namely, that opposition becomes a part of a narrative of transformation and discovery.

It is hard to overstate the importance of discovery in Edwards's experimental religion. Time and again he focuses on the discontinuity between what the mind of natural man and supernatural man can perceive. But Edwards does not suggest that this discovery is anything else than a personal, revelatory experience over which clergy, parents, social position, or education has little control. Discovery itself is the separating experience as well as the telos of experimental religion. Edwards formulates it in two ways:

And besides the things that have been already mentioned, there arises from this sense of spiritual beauty, a true experimental knowledge of religion; which is of itself, as it were a new world of knowledge. ... And were it not for the very imperfect degree, in which this sense is commonly given at first, or the small degree of this glorious light that first dawns upon the soul; the change made by this spiritual opening of the eyes in conversion, would be much greater, and more remarkable, in every way, than if a man, who had been born blind, and with only the other four senses, should continue for so long a time, and then at once should have the sense of seeing imparted to him, in the midst of the clear light of the sun, discovering a world of visual objects.... Yet this spiritual sense is ... infinitely more noble than that, or any other principle of discerning that a man naturally has, and the object of this sense infinitely greater and more important. (275)

And besides all this, the truth of all those things, which the scripture says about experimental religion, is hereby known; for they are now experienced. And this convinces the soul that one who knew the heart of man, better than we know our own hearts, and perfectly knew the nature of virtue and holiness, was the author of the Scriptures. And the opening to 
view, with such clearness, such a world of wonderful and glorious truth in the gospel, that before was unknown, being quite above the view of a natural eye, but now appearing so clear and bright, has a powerful and invincible influence on the soul to persuade of the divinity of the gospel. (303)

Religious experience for Edwards is the discovery of God's holiness that flowers out into an "infinite ocean," a "new world of knowledge," enough to satisfy the soul, that not only withstands scrutiny but that overcomes threats, bringing them to order by the same principle that enlivens the soul. Inquiry is not just a handmaid to theology but is itself the way we discover the reality of an opposing order in "the things that are made," an order that can be experienced and articulated so that it brings our reflective consciousness to stability. Participating in this discovery for Edwards cannot mean turning one's back on intellectual engagement or breaking with the Christian tradition. Rather it entails establishing the limits of self-understanding as it appears in the narrative and reflective accounts of our lives.

The systematic breadth of Edwards's experimental religion seems both attractive and oppressive. Edwards's Calvinism lost its appeal because of its determinism and rational coldness. But Edwards's holistic religious vision still attracts attention from theologians, philosophers, rhetoricians, and historians.

Edwards's fate in our interpretive hands reflects this conflict of desire. On one hand we demand an ideal, all-incorporating structure of experience, as evidenced by the continuing influence of idealism in American philosophy. John Dewey stands in Edwards's wake when he lowers the wall between sacred and secular values in order to fulfill our demands for a holistic account of experience, whether he acknowledges it as ideal or not. On the other hand, Edwards offends our desire for plurality and freedom because of his religious tradition and his absolutist philosophical mien. For Dewey and those naturalists in his line the religious and confessional character of Edwards's systematic breadth is oppressive and philosophically suspicious. Still, we hope for such a philosophy that can provide the reflective stability we need for our pursuit of meaning and community while being open enough to incorporate us all and all of us.

Despite the fact that Edwards never produced a systematic philosophy, there is an elusive wholeness to his thought, like the object that awakens the spiritual sense to the promise of a unity of the heart and the harmony of the soul. Edwards's systematic wholeness appears and 
vanishes, yet it remains a vague residue in our reading and in the cultural acceptation of his thought and character.

If there is an object that shows Edwards's reflective wholeness, it is his experimental religion based on the kind of conversion described in the Religious Affections. Conversion incorporates the aesthetic sense, the integrity of the understanding and the will, the truth of the scriptural witness, and public moral life. These themes taken together give us Edwards's most complete understanding of the whole person. ${ }^{29}$ Edwards's conviction that conversion reflects "God's absolute sovereignty" raises the signs of affection as the paradigm of experimental religion. The reflective tension of conversion, articulated within the twelve signs, is arguably the tension "proper" to religion as its most revealing trial in showing the soul's reorientation. The authority of this tension grounds Edwards's hope:

Whenever a person finds within him, an heart to treat God as God, at the time that he has the trial, and finds his disposition effectual in the experiment, that is the most proper, and most distinguishing experience. And to have at such a time that sense of divine things, that apprehension of the truth, importance and excellency of the things of religion, which then sways and prevails and governs his heart and hands; this is the most excellent spiritual light, and these are the most distinguishing discoveries. (451)

My purpose in this chapter has been to show the significance of the structure of conversion in Edwards's Religious Affections. My larger goal, however, has been to call attention to the centrality of conversion in Edwards's larger philosophical and theological enterprise. Edwards's reflective holism is significant for American philosophy and theology today because we are still working from an origin that is peculiarly American, peculiarly Christian, and peculiarly "experimental." The proof of this larger hypothesis of Edwards's significance for American thought requires a continuous reading of our tradition, and the structure of conversion will, I hope, give evidence of its usefulness by the results of further inquiries into Edwards and beyond.

\section{NOTES}

1. Jonathan Edwards, Religious Affections: The Works of Jonathan Edwards, vol. 2 (Yale University Press, 1959). Parenthetical notes refer to this volume.

2. Iain H. Murray, Jonathan Edwards: A New Biography (Banner of Truth Trust, 1987), 207. 
3. Two examples are Robert Jensen's America's Theologian: A Recommendation of Jonathan Edwards (Oxford University Press, 1988) and Anri Morimoto's Jonathan Edwards and the Catholic Vision of Salvation (Pennsylvania State University Press, 1995). Jensen argues that Edwards avoids the traps of modernism in his theological development, and Morimoto argues for a strong connection between Edwards and Roman Catholic sotierology. These are only two examples but are representative of two significant orientations of Edwards scholarship.

4. Perry Miller, Jonathan Edwards (World Publishing, 1959).

5. Sang Hyun Lee, The Philosophical Theology of Jonathan Edwards (Princeton University Press, 1988).

6. John Smith, Jonathan Edwards: Puritan, Preacher, Philosopher (University of Notre Dame Press, 1992).

7. I Peter 1:6.

8. John Smith, in the introduction to the Yale edition of Religious Affections, comments only that the signs must not be a recapitulation of the Puritan order of salvation he was opposed to. But Smith does not consider the possibility that Edwards is proposing another structure, one quite different from the tradition. Claude Newlin, Philosophy and Religion in Colonial America (Philosophical Library, 1962), states that the first four signs summarize Puritan theology, but does not address the rest. Michael Raposa develops the relation of the twelfth sign to Peirce's pragmaticist position, but gives only a glancing description of the supporting edifice on which this sign is built. "Jonathan Edwards's Twelfth Sign,” International Philosophical Quarterly 33, no. 2 (1993): 153-162.

9. Collected Papers of C. S. Peirce (Harvard University Press, 1934), 6:457: "If God Really be, and be benign, then, in view of the generally conceded truth of religion, were it but proved, would be a good outweighing all others, we should naturally expect that there would be some Argument for his Reality, that should be obvious to all minds, high and low alike."

10. Vincent Colapietro, Peirce's Approach to the Self (SUNY Press, 1989), 105. See also Roger A. Ward, “C. S. Peirce and Contemporary Theology: The Return to Conversion," American Journal of Theology and Philosophy 16, no. 2 (May 1995): 125-148.

11. See "A Neglected Argument for the Reality of God" and "The Law of Mind," two essays in which Peirce deals with teleological significance of human thought and habit change.

12. Subsequent American thinkers have also expressed a tendency to focus descriptions of value on analyses of change, a tendency I am willing to argue is more or less rooted in this theological conviction of Edwards. I include in this list Dewey, Peirce, Miller, Rorty, and West.

13. "A Divine and Supernatural Light," in A Jonathan Edwards Reader (Yale University Press, 1995), 111. 
14. Ibid.

15. Ibid., 123-124.

16. Ibid., 106.

17. Charles Hodge uses Edwards against Edwards A. Park; for instance, in "The Theology of the intellect and that of the feelings, II," Essays and Reviews (Robert Carter and Brothers, 1857), $571 \mathrm{ff}$., Hodge states, "Our puritan fathers adhered to the doctrine of original sin as consisting in the imputation of Adam's sin, and in a hereditary depravity; and this continued to be the received doctrine of the churches of New England, until after the time of Edwards. He adopted the view of the Reformers on the subject of original sin and a depraved nature transmitted by descent. But after him this mode of stating the subject was gradually changed, until long since, the prevailing doctrine in New England has been that men are not guilty of Adam's sin, and that depravity is not of the substance of the soul, but is wholly voluntary and consists in a transgression of the law in such circumstances as constitute responsibility and desert of punishment" (575). And further, "We refer our readers to President Edwards's work on Original Sin, and request them to notice with what logical strictness he demonstrates that the denial of the sinfulness of human nature and the assertion of plenary power of men to obey the commands of God, subverts the whole plan of redemption" (593). It is clear that Hodge sees Edwards in fundamental agreement with his own orthodoxy.

18. Jonathan Edwards, "The Mind," Scientific and Philosophical Writings: The Works of Jonathan Edwards (Yale University Press, 1980), 6:332-394.

19. Edwards, "The Mind," 337.

20. Conrad Cherry, The Theology of Jonathan Edwards (Indiana University Press, 1966). Cherry's emphasis on the incitement to trust and humility from the "posture" of perceiving the excellence of God is certainly correct. What Cherry does not account for as well, though, is the structure of the understanding Edwards depends on to describe this incitement and transformation. 77ff.

21. The Works of President Edwards (S. Converse, 1829), 1:60.

22. Sang Hyun Lee, Philosophical Theology, 166. Lee's discussion of the ontological task of imagination in Edwards's thought does well to describe the disposition of the mind enabled to decipher the structure of reality. Where I find a lapse in Lee's argument, however, is the relation to objective content necessary for this work of the imagination. For Edwards the mind functions according to its nature only in relation to the objective content of revealed truth, and otherwise it is liable to deception.

23. Smith, Jonathan Edwards, 24. Smith discriminates Edwards's difference from Locke on the issue of an order in the mind that is embodied in habit, but is not necessarily "before" the mind "in order for the person to follow the habit." I associate this "order" with the "new simple idea" Edwards connects to "metaphysicians" in the first sign of gracious affections. Edwards enhances 
Locke's description of the order of ideas with his claim that the internal structure of "simple ideas" is the ground of substance, or resistance, that makes relations and judgments possible. For Edwards, this becomes the ultimate ground of personal identity and his most marked rejection of Locke. See "The Mind," 386.

24. "The Mind," 386-387. Edwards comments that Locke's description of identity cannot explain the "train of ideas" that constitutes a "person" without the joys and sufferings that affect the tendency of mind. He follows this thought with an outline for a treatise on the mind where he intends to deal with "the influence of prejudice to cloud the mind." The power of prejudice in undermining the ability of understanding is the negative statement of the point made here, that all understanding is reflective of a tendency toward an object, and this object determines the character of the understanding.

25. Bishop Butler, Analogy of Religion (Harper and Brothers, 1889). The Analogy was first published in 1736. The moral sense Butler describes is one of "propensions, together with moral understanding, as well as including a practical sense of virtue ... forming an inward constitution," 156.

26. Cherry, Theology, 78. Cherry notes the Augustinian and Calvinistic roots of the subsistence of the "old man and new man" together in one person. I am suggesting here that Edwards not only continues this tradition (see sign VII) but that he also incorporates this tension into the dialectic proper to the faculty of understanding.

27. Original Sin: The Works of Jonathan Edwards (Yale University Press, 1970), 3:313-314. "This grand distinction between the two Adams, and the other instances of opposition and difference, here insisted on [Rom. 5:12ff] as between the effects of sin and righteousness, the consequences of obedience and disobedience, of the offense and the free gift, judgment and grace, condemnation and justification, they all come to nothing; and this whole discourse of the Apostle's wherein he seems to labor much, as if it were to set forth some very grand and most important distinctions and oppositions in the state of things, as derived from the two great heads of mankind, proves nothing but a multitude of words without meaning, or rather a heap of inconsistencies."

28. But even this notion of "complete" is not without qualification. No sooner does Edwards articulate the "perfect universal obedience" of the saint then he introduces a codicil about the character, which bears failure in particulars but integrity in its wholeness, using King David and Saint Peter as the two prime examples (384).

29. Smith, Jonathan Edwards, 44. Smith notes the oddity that so basic a sign as conversion does not appear until the middle of Edwards's signs in the Religious Affections. This odd fact has propelled this study to discover the harmony of Edwards's signs. 